\title{
POST-GENOMIC TECHNOLOGIES FOR THE ADVANCEMENT OF OIL PALM RESEARCH
}

\section{SUBHI SITI MASURA *; NOOR IDAYU TAHIR*; OMAR ABD RASID*; UMI SALAMAH RAMLI*; ABRIZAH OTHMAN*; MAT YUNUS ABDUL MASANI*; GHULAM KADIR AHMAD PARVEEZ ${ }^{\star}$ and KUSHAIRI, ${ }^{*}$}

\begin{abstract}
For a century, Malaysia has been bestowed with oil palm as one of its economic drivers. In the recent decades, the industry witnesses a major breakthrough in oil palm research with the success of oil palm genome sequencing. The access to genome information opens a new door for the crop improvement towards higher yield and quality. Herein, we highlight the harnessing of this opportunity via genetic engineering, coalesced with transcriptomics, proteomics and metabolomics techniques to lay a foundation for comprehensive and systematic crop advancement programme. With the extensive complement of genes, promoters and constructs for oil palm, and the development of reliable transformation systems, genetic engineering programme has been embarked with an objective to fulfil and sustain the growing global need for oils and fats. The production of transgenic oil palm has been reported and this achievement has further created an opportunity towards genome editing. Spectrometry detection and measurement of oil palm biochemical components aided with chemometrics data interpretation further reinforce post-genomic investigation with in-depth understanding of oil palm biology. The availability of genetic engineering system and the application of omics platform on the genome-wide association study outlined in this article create an unprecedented prospect for oil palm improvement programme.
\end{abstract}

Keywords: post-genomics technologies, genetic engineering, omics research.

Date received: 16 October 2017; Sent for revision: 17 October 2017; Received in final form: 20 November 2017; Accepted: 21 November 2017.

\section{INTRODUCTION}

The chronicle of oil palm (Elaeis guineensis Jacq.) in Malaysia describes the humble origin of the species from West Africa until its eminence as an important crop and commodity for this prospering country. The rapid increase in plantation area from merely 400000 ha in 1972 to 5.74 million hectares in 2016 (Kushairi, 2017) indicates the economic significance of this plantation crop. In tandem with the increase in area of cultivated palm, Malaysia's annual export of palm oil has also risen steadily from 1.17 million tonnes

\footnotetext{
Malaysian Palm Oil Board,

6 Persiaran Institusi, Bandar Baru Bangi,

43000 Kajang, Selangor, Malaysia.

E-mail: masura@mpob.gov.my
}

in 1975 to 16.05 million tonnes in 2016 (Kushairi, 2017). The performance of palm oil is impressive and has maintained growth in the global market by contributing to $55 \%$ of the world's production of oils and fats (Kushairi, 2017). It has been known as a high-yielding source of vegetable oil which is widely consumed in food and oleochemical industries, and has been increasingly used for biofuel. The palm oil industry has grown rapidly with an expansion of upstream and downstream sectors and has been identified as one of the key players in elevating the Malaysian socio-economy towards becoming a high-income nation by 2020 (Choo, 2012). Despite these economic advantages, the industry faces several challenges such as climate change, pests and diseases, limitation of arable farmland as well as increasing oil for food demand due to the 
growing world population (Low et al., 2016). Thus, in order for the industry to remain competitive yet sustainable, a comprehensive strategy needs to be developed through the improvement of oil palm quality and yield.

The production of 4-6 t oil per hectare should be increased to more than $10 \mathrm{t} \mathrm{ha}^{-1}$ (Parveez et al., 2015a; Murphy, 2014) in the existing arable land, as the rapid expansion on agriculture may cause devastating impact on biodiversity (Bhore, 2013). The first wave of oil palm improvement success was achieved through conventional breeding. An impressive increase in oil yield was accounted since more than 50 years ago with an average of $1 \%$ genetic gain per year (Rival and Jaligot, 2010). However, the technology is resource and time-intensive that takes more than 12 years for one selection cycle (Sambanthamurthi, 2016), and is limited by a narrow gene pool (Parveez et al., 2015a). Hence, complementing this established breeding technique with novel approaches from biotechnology will accelerate the progress in oil palm improvement (Ramli et al., 2016; Murphy, 2014). Application of agricultural biotechnology through the discovery of molecular markers or genetic engineering approach has increased the productivity of many crops. The global market for agricultural biotechnology products was worth USD 15.3 billion in 2012, and it is expected to double by 2019 (Arujanan, 2016). Therefore, the Malaysian Palm Oil Board (MPOB) plays a significant role to pioneer and promote oil palm biotechnology in efforts to expedite the production of improved planting materials. The technology is being developed with the focus on three main areas, viz. i) increasing oil yield, ii) modifying fatty acid composition, and iii) developing oil palm with pest and disease tolerance (Parveez et al., 2015a; Murphy, 2014).

Multidisciplinary approaches such as genomics, transcriptomics, proteomics and metabolomics are being developed and adopted to pave this endeavour forward. The accomplishment of oil palm genome sequencing has given a major impact in oil palm research, with over 30000 oil palm genes sequenced, and the genome assembly and annotations being continuously improved (Low et al., 2016; Singh et al., 2013). The wealth of genomic information has created the opportunity to diversify and accelerate oil palm modification using various post-genomics approaches. In linking genes to traits, omics approach enables the systems biology reconnaissance at the molecular, cellular and biochemical levels by delineating interactions between genes, proteins, and metabolites within a specific phenotype (Emon, 2016). Hence, the advancement of omics platforms has provided valuable resources for the discovery, assessment and establishment of molecular markers and precise gene modification through genetic engineering.
In addition to higher precision of gene modification, genetic engineering also offers several other benefits including reduction of cost and time for introgressing the desired traits and the potential to broaden the plant genetic base (Sambanthamurthi et al., 2009). Genetic modification involves insertion of transgenes into plant either using sense or antisense technologies. Introducing of sense sequences is necessary for upregulating the targeted genes. However, both technologies can be used to downregulate or silence target sequences. The ribonucleic acid interference (RNAi) technology was later developed and emerged as a precise, efficient, stable and better than antisense technology for gene suppression (Duan et al., 2012; Younis et al., 2014). However, as the technology rapidly evolved, the route of genetic engineering has been shifted to gene or genome editing which does not involve the transfer of foreign genes, and promises lesser regulatory scrutiny and public concerns (Arujanan, 2016). This technique is an efficient and powerful tool, which requires the availability of genome and transcriptome information, coalesced with an efficient genetic transformation tool. Thus, the effort to establish oil palm genetic transformation and the instrumental discoveries from omics research will be looked in-depth, as these post-genomics approaches have promised quantum leap improvement of oil palm with beneficial traits.

\section{HARNESSING GENOME INFORMATION FOR OIL PALM IMPROVEMENT}

Once a genome sequence of an organism has been assembled and annotated, a deeper understanding of genetics factor can help researchers expound basic components and variations that determine the traits and their heredity. Optimum utilisation of the sequenced oil palm can now be carried out with the genome information at our disposal. Research on oil palm genetic modification escalated in the mid of 1990s, with a high endeavour to channel its inherent high productivity towards value-added products (Parveez et al., 2015a). As a basis of precision gene modification through genetic engineering, an effort to understand omics complex interaction in oil palm biological system is very important. The proteomics and metabolomics research can accurately monitor and profile a variety of molecular processes that facilitate the identification of biological traits, such as high yielding, disease resistance, good oil quality and clonal/transgenic palm (Ramli et al., 2016). Such advanced platforms provide an inclusive insight towards manipulating the oil palm targeted pathways, such as fatty acid and carotenoid biosynthesis pathways and plant defence mechanisms. 
Adding value to oil synthesis is an important improvement; and in other oil-bearing crops this is achieved by manipulating fatty acid biosynthesis pathway. In soyabean, cotton and Jatropha, the increment of oleic acids was obtained by reducing linoleic acid (Graef et al., 2009; Liu et al., 2000; Qu et al., 2012), while the stearic acid in Brassica napus increased with a concomitant reduction in oleic acid (Knutzon et al., 1992). Besides, in canola, modifying its very long chain fatty acids (VLCFA) resulted in a significant increase in cosenoic, erucic and nirvanic polyunsaturated fatty acids (Lassner et al., 1996). Likewise, the omega-3 fatty acid such as eicosapentaenoic (EPA) and docosahexaenoic (DHA) that are essential for human dietary could be produced in plants by a stepwise metabolic engineering of long chain polyunsaturated fatty acids (LC-PUFA), through the expenses of $\alpha$-linoleic acid (Betancor et al., 2017; Ruiz-Lopez et al., 2013). These studies denoted the huge potential of plants to serve as a cost-effective and sustainable factory or bioreactor in generating value-added products. As a perennial crop, oil palm will gain most of these advantages, as the value-added products can be harvested for at least 25 years (Manaf et al., 2017).

The main target of oil palm genetic engineering is to increase oleic acid, which is used as an important feedstock in oleochemicals industry (Parveez et al., 2015a). Other targets of oil palm genetic engineering work are to produce high stearic acid, high palmitoleic acid, lycopene, high ricinoleic acid and biodegradable plastics (Parveez et al., 2000; 2003; 2015a). In general, the comprehensive strategies for modifying these targeted value-added products in oil palm have been critically reviewed by Parveez et al. (2015a) and Manaf et al. (2017). The isolation of key important genes involved in medium and long chain fatty acids and carotenoid biosynthesis were also reported (Table 1). In addition to gene isolation, focus has also been given to the isolation of regulatory or promoter sequences. To ensure that the expression of transgenes for the production of genetically engineered products is directed to the targeted tissue, promoter sequences that are responsible to direct the expression of the desired genes have been identified. The oil palm tissue specific promoters from mesocarp, kernel, leaves and roots, as well as constitutive promoters have been isolated and fully characterised (Table 2). The genes were identified using various molecular approaches such as northern analysis, reversetranscription polymerase chain reaction (RT-PCR), suppression subtractive hybridisation (SSH) and expressed sequence tags (EST). The gene function studies were carried out in either bacterial host system and/or model plants such as Arabidopsis thaliana (Abrizah et al., 2000; Ramli et al., 2012; Hanin et al., 2016; Parveez et al., 2010; Safiza et al., 2009a; Zubaidah et al., 2017), tobacco (Izawati et al., 2017a, Bahariah et al., 2012) and tomato (Izawati et al., 2017a).

In addition to modifying oil content, managing the challenge of Ganoderma infection that causes basal stem rot disease is also one of the concerted biotechnological approaches for increasing oil yield. Effort to investigate the interaction between oil palm and Ganoderma has been initially performed at the molecular level through identification of important genes involved in the oil palm defence mechanisms (Safiza et al., 2015; Manaf et al., 2017). A number of genes from Ganoderma, that are highly expressed during infection and potentially involved in fungus pathogenicity have also been isolated and characterised (Lim et al., 2014; 2016; Fakhrana et al., 2011; Rasid et al., 2014b). Such comprehensive research can provide an inclusive understanding of

TABLE 1. THE GENES ISOLATED AND CHARACTERISED FROM OIL PALM

\begin{tabular}{|c|c|c|}
\hline Gene & Function & References \\
\hline Acetyl-CoA carboxylase & Fatty acid synthesis & Wan Saridah et al. (2008) \\
\hline Ketoacyl ACP synthase II (KAS II) & Fatty acid synthesis & $\begin{array}{l}\text { Ramli and Sambanthamurthi (1996), Ramli et al. (2012) } \\
\text { Mapped by Montoya et al. (2013) }\end{array}$ \\
\hline Palmitoyl-ACP thioesterase & Fatty acid synthesis & Abrizah (2001), Abrizah et al. (2000), Parveez et al. (2010) \\
\hline Stearoyl ACP desaturases & Fatty acid synthesis & $\begin{array}{l}\text { Rasid and Shah (1996), Siti Nor Akmar et al. (1999), } \\
\text { Safiza et al. (2009a) } \\
\text { Mapped by Montoya et al. (2013) }\end{array}$ \\
\hline Oleoyl-ACP-thioesterase & Fatty acid synthesis & $\begin{array}{l}\text { Asemota et al. (2004) } \\
\text { Mapped by Montoya et al. (2013) }\end{array}$ \\
\hline Oleoyl-CoA desaturase & Fatty acid synthesis & Syahanim et al. (2007) \\
\hline Acetyl-CoA carboxylase & Fatty acid synthesis & Omar et al. (2008) \\
\hline Lysophosphatidic acid acyltransferase & Triacylglycerol synthesis & Manaf et al. (2005), Safiza et al. (2009b) \\
\hline Lipase & Lipid breakdown & Nurniwalis et al. $(2008 ; 2015)$ \\
\hline Phytoene synthase & Carotenoid synthesis & Rasid et al. (2008) \\
\hline Phytoene desaturase & Carotenoid synthesis & Rasid et al. (2014a) \\
\hline
\end{tabular}


TABLE 2. TISSUE-SPECIFIC AND CONSTITUTIVE PROMOTERS ISOLATED FROM OIL PALM

\begin{tabular}{lll}
\hline Type of promoter & Promoter & References \\
\hline Mesocarp-specific & MT3-A promoter & Siti Nor Akmar and Zubaidah (2008) \\
& FLL1 promoter & Nurniwalis et al. (2015) \\
Kernel-specific & pOP-KT21 & Siti Nor Akmar et al. (2014) \\
Root-specific & MT3-B & Zubaidah and Siti Nor Akmar (2005) \\
Leaf-specific & LS01 & Chan et al. (2008) \\
Constitutive & uep1 & Masura et al. (2010) \\
& TCTP & Masura et al. (2011) \\
\hline
\end{tabular}

fungus and host interactions to facilitate effective strategies for controlling or eliminating the disease spread.

Although the full complement of the genes and promoters for oil palm genetic modification is already in hand, work to discover more novel endogenous genes and promoters is still on-going. The availability of oil palm and Ganoderma genome data with abundant transcriptome information provide new and powerful tool for gene isolation and expression studies. Recently, a number of oil palm mesocarp-specific genes have been identified through meta-analysis of multiple transcriptome dataset (Siti Suriawati et al., 2016). The use of meta or RNA-seq analysis for profiling the transcriptome has aided the expression study of different transcript isoforms, and allowed comparison to be made for isoform diversity and abundance (Malone and Oliver, 2011). The identification of correct isoform is very important in modification of oil palm traits because the different isoforms from the same gene can produce proteins that have different properties and functions. Thus, complementing the advance RNA-seq approach with other functional genomics tools, such as Seqping analysis (Chan et al., 2016) and RT-qPCR will certainly accelerate the discovery of oil palm potential genes essential for oil palm transformation.

\section{Development of Oil Palm Transformation Systems}

Establishment of reliable and efficient plant transformation systems is an absolute prerequisite for any genetic engineering programme (Birch, 1997). With an effective transformation system, the transformed genes could stably integrate into the plant genome and express over generations. The feasibility of transforming oil palm was demonstrated in the end of 1990 (Abdullah et al., 1996; Chowdhury et al., 1997; Parveez et al., 1997; 2000). This was achieved through particle bombardriant or biolistics gene delivery method, following the comprehensive efforts in identifying the most effective constitutive promoter and the best selection agents to select transformed oil palm cells (Chowdhury et al., 1997; Parveez, 2000; Parveez et al., 1996; 1997; 1998). Since then, an extensive effort has been made towards improvement of oil palm traits, focusing on the development of various gene delivery methods, transformation vector constructions, application of different selection agents and evaluation of starting materials.

The Agrobacterium mediated transformation has been developed for oil palm and a successful protocol was reported for oil palm calli (Masli et al., 2009; Izawati et al., 2015) and immature embryo (Abdullah et al., 2005; Fuad et al., 2008). Agrobacterium mediated transformation protocols are advantageous for precise insertion of transgenes with low copy numbers and relatively high transformation efficiency. In addition to gene delivery methods, the availability of effective transformation vectors are important determinants for the success. The transformation vectors for each of targeted traits, carrying the isolated genes and promoters, were constructed (Parveez et al., 2015a). The vectors contain multiple-genes flanked with matrix attachment region (MAR) as means to reduce the incidence of gene silencing as well as to enhance transgene expression (Yunus and Kadir, 2008; Yunus et al., 2008; Masani et al., 2009). The vectors were transformed into oil palm embryogenic calli which later regenerated on Basta selection. In order to increase the transformation efficiency, oil palm transformation was performed by using visual selection agent such as green fluorescence protein (GFP) (Majid and Parveez, 2007; Parveez and Majid, 2008). However, possibly due to the cell toxicity, the cells transformed with $g f p$ gene were unable to express GFP in whole plant (Majid and Parveez, 2016; Manaf et al., 2017). The positive selection markers including phosphomannose isomerase (pmi) (Bahariah et al., 2012; 2013) and 2-deoxyglucose (2-DOG) (Izawati et al., 2012; 2015) were also evaluated for oil palm transformation. The regeneration of some oil palm transgenic lines under Basta, 2-DOG and pmi selections has been reported (Bahariah et al., 2012; 2013; Izawati et al., 2015; Parveez et al., 2015b; Nurfahisza et al., 2014). Some of the regenerated transgenic lines were transferred to soil and grown in a biosafety screenhouse.

Despite the success, the transformation efficiency obtained for oil palm is relatively low, between $0.7 \%$ and 1.5\% (Parveez, 2000; Masli et 
al., 2009). The initial molecular analysis showed the recovery of nearly $90 \%$ transgenic lines at the plantlet stage (Parveez et al., 2003). However, after 7-8 years, the unstable integration of transgene into oil palm genome in some of transgenic lines was detected (Nurfahisza et al., 2014). This could be due to the non-optimal selection, which allowed the regeneration of chimeric plants that carry both transgenic and non-transgenic tissues. The condition could also allow the presence of escapes. Transgene integration is predominantly a random process, which depends mainly on factors such as methylation, integration site of transgene and position effect (Gandhi et al., 1999). Hence, in order to increase the stability of transgene integration into oil palm, a recalcitrant crop with a more complex genome, further improvement of the developed transformation protocols has to be performed.

The various aspects of transformation are currently being evaluated in efforts to effectively improve the efficiency of oil palm transformation. Optimisation of biological and physical parameters affecting stable integration of transgenes using biolistics and Agrobacterium mediated transformation is among the main focus for increasing oil palm transformation efficiency. Evaluation of these parameters for Agrobacterium mediated transformation in wheat (Cheng et al., 2003), rice (Hiei and Komari, 2006; Priya et al., 2012), carnation (Zuker et al., 1999), banana cv Rastali (Subramanyam et al., 2011), soyabean, flax and chickpeas (Trick and Finer, 1998; Beranova et al., 2008; Pathak and Hamzah, 2008) significantly increased the transformation efficacy. Likewise, optimisation of these parameters for biolistics also increased the transformation efficiency of many plants such as soyabean, bean, cotton, wheat, Coffee arabica and Brassica rapa (Rech et al., 2008; Fadeev et al., 2006; Gatica et al., 2009; Young et al., 2008).

In addition to Basta ${ }^{\circledR}$, the effect of other bar base selection agents such as glufosinate ammonium and bialaphos was also evaluated to tighten the oil palm selection. Basta ${ }^{\circledR}$ is a chemical herbicide formulated using glufosinate ammonium, an ammonium salt of phosphinothricin (Fromm et al., 1990). Meanwhile, bialaphos is natural herbicide synthesised from bacterial strains either by Streptomyces hygroscopicus or Streptomyces viridochromeogenes, which consist of L-phosphinothricyl-L-alanyl-alanin (Dennehey et al., 1994). As the sensitivity of selection agent is tissue, age and genotype dependent (Eustice and Wilhelm, 1984), efforts to evaluate the efficiency of these selection agents at the different growth stages of embryogenic calli (EC) were carried out. The optimal concentrations of these bar base selection agents to inhibit the growth of embryogenic calli and embryoid were reported by Nurfahisza et al. (2015). In addition, the efficacy of other selection agents for oil palm transformation has also been evaluated. In addition to herbicide Basta ${ }^{\circledR}$, hygromycin was also identified as a suitable selection agent for isolation of transformed cells from oil palm EC (Parveez et al., 1996; Bahariah et al., 2017) and immature embryos (IE) (Parveez et al., 2007; Abdullah et al., 2005). The effective inhibitory concentrations of hygromycin for four different types of EC, such as suspension culture, fine EC, yellowish and whitish EC were reported by Fakhrana et al. (2015).

EC has been used as starting materials as it was reported to be a good target tissue for transformation (Izawati et al., 2015). EC provides a source of dividing cells and has unique homogenous characteristics. The suitability of immature EC as starting material for oil palm transformation has been evaluated (Masura et al., 2017). Several studies indicated that the use of calli at an earlier or immature stage has significantly improved the transformation efficiency (Ribas et al., 2011; Manimaran et al., 2013). The friability and lack of differentiation of immature EC in early callus proliferation may facilitate an effective in vitro selection, thereby minimising the chance of escapes. Oil palm plantlets resistant to glufosinate ammonium from immature EC were successfully obtained. Initial molecular analysis via PCR indicated that some of the plantlets carrying the high oleate traits were positive for bar gene (Masura et al., 2017).

The potential of IE as alternative starting materials for oil palm transformation has also been explored. The direct regeneration of transgenic oil palm from IE was reported by Abdullah et al. (2005). However, molecular evidence describing the stable integration of transgenes has not been reported so far. While, Bhore and Shah (2012), also demonstrated the effort to transform Elaeis oleifera using IE. In fact, in the first report of successful oil palm transformation, the EC that was derived from IE was used as the target tissue (Parveez, 1998). Thus, the effort to propagate calli from IE has been carried out extensively, by evaluating the culture media for regeneration of whole plants from IE. The initial data has demonstrated that MS+Y3 medium was the most suitable medium for IE callus induction (Syuhada et al., 2016). In addition to Elaeis guineensis var tenera species, the rigorous experiments have been also carried out to look into the possibility of using dura for oil palm transformation. As mother palm, dura has advantages to be used for crossing and backcrossing to regenerate transgenic lines, which is unfeasible if using tenera. The comprehensive optimisation of biological and physical parameters affecting biolistics transformation of dura has been performed (Izawati et al., 2017b).

Development of novel methods for transforming oil palm via protoplast has opened a new door for oil palm improvement, especially to circumvent issues related to current protocol of producing transgenic oil palm. The successful transformation of oil palm 
protoplasts using microinjection and PEG-mediated transformation was reported (Masani et al., 2014). The use of protoplast as starting materials is beneficial for oil palm genetic engineering because regeneration of transgenic plants from single transformed cell would potentially eliminate the chances of escapes and chimeras (Masani et al., 2013; 2014). Moreover, the oil palm protoplast system will also serve as an invaluable tool for gene functional studies either for genetic modification or genome editing approaches, as the evaluation of gene function could be performed within a shorter timeline (3-5 years) as opposed to the stable Agrobacterium-mediated transformation and biolistics systems (5-10 years).

\section{OMICS REVOLUTION IN OIL PALM RESEARCH}

Omics technology promises consistency and predictability in plant breeding towards better yield and quality food crops. Several emerging omics technologies have been introduced to oil palm research for unravelling the molecular mechanisms of oil palm system biology under various conditions. In the area of oil palm genome, the release of the genetic blueprint of the oil palm is considered to have major implications in enhancing the future production and sustainability of the oil palm industry (Ong-Abdullah et al., 2015; Singh et al., 2013).

Understanding the changes of target molecules such as proteins, transcripts, fatty acids and various metabolites provides insights beyond the molecular mechanism of complex traits such as yield and oil palm diseases. This integrated approach relies heavily on many disciplines of biology, analytical methods and computation analysis (Mochida and Shinozaki, 2011). Therefore, recent innovative analytical platforms comprising essential infrastructure such as mass spectrometry for proteomics and metabolomics research in oil palm have been established (Ramli et al., 2016).

The omics methodologies applied in oil palm research have facilitated extensive discoveries of indicative transcripts, proteins and metabolites associated with yield traits such as fruit ripeness, fruit quality, fruit form and lipid formation (Wong et al., 2017; Hassan et al., 2016; Ooi et al., 2015; Teh et al., 2014; 2013; Loei et al., 2013; Neoh et al., 2013; Dussert et al., 2013; Hassan et al., 2014). Chromoplasts of coloured fruits such as ripe oil palm drupes contain plastoglobules, lipid-containing structures present in all types of plant plastids. This plastoglobules amass carotenoids (xanthophyll esters), $\alpha$-tocopherol and quinones in the central core, with their polar head groups oriented outward interacting with a protein coat (Ytterberg et al., 2006).
Due to the fact that plant chromoplasts possess active metabolism and the ability to synthesise some of their structural components, proteins from the organelle are indispensable for many physiological processes (Ljubešić et al., 1991). Although there is much knowledge of genes coding for the proteins and the products of lipid biosynthesis pathway in higher plants, the fatty acid biosynthetic and other cellular metabolic pathways remain unclear at the protein level. Au fond, characterisation of fatty acid biosynthetic enzyme expression in the oil palm mesocarp tissue will help expound this conundrum (Lau et al., 2015).

Integrated omics approach requires precision chemical analytical methods and informatics with the focus on key traits of interest (Emon, 2016). When evaluating large and multi-dimensional omics data sets e.g. combination of electrophoresis or chromatography and mass spectrometry measurements for comparative purposes such as contrasting treatments and traits or gradual changes such as growth, pattern recognition statistics such as chemometric are employed to expedite data interpretation. From a dataset containing information on concentrations, intensity or spectral properties along with sample identifier e.g. name or accession number, omics data can be processed into informative graphics. Thousands of transcripts, proteins and/or metabolites from various samples can be compared for any distinction that is relevant to their particular condition.

Coupled with mass spectrometry, separated biomolecules from oil palm biological replicates of different traits or treatments can be analysed comparatively by multivariate statistics such as principal component analysis (PCA) and partial least square-discriminant analysis (PLS-DA). This platform is very effective in discovery analysis such as in oil palm disease study. Figure 1 shows a PLSDA scores plot from gas chromatography-mass spectrometry (GC-MS) analysis of leaf metabolome from oil palm with different Ganoderma boninense susceptibility backgrounds (Rozali et al., 2017).

As a consequence of pathogenic aggression on oil palm, biochemical responses of both the infectious agent and host will be stimulated as part of their respective attack and defence strategies. In the case of $G$. boninense infection, physical symptoms such as rotting, necrosis and presence of fruiting bodies do not appear until the disease is at a critical stage, resulting in loss of standing palms (Nurazah et al., 2017). Several detection and control measures have been initiated to tackle this disease as early as possible ranging from remote sensing to hyperspectral reflectance statistical model (Chong et al., 2017; Lelong et al., 2010) but the inclusive comprehension of the fungal attack needs to be grasped in order to fully manage the disease spread or even eliminate this threat. 
The application of transcriptomics, proteomics and metabolomics has been employed to investigate the interactions between oil palm and G. boninense fungus (Nusaibah et al., 2016; Dzulkafli et al., 2016; Tee et al., 2013; Nurazah et al., 2013; Alizadeh et al., 2011; As'wad et al., 2011). Table 3 lists differentially expressed proteins in both oil palm roots and $G$. boninense during several separate inoculation experiments which are responsible for the survival of both the host and the pathogen. These findings, along with cohesive exploration with transcript and metabolome profiling may provide inclusive insights into pathogenicity of G. boninense towards oil palm or even tolerance of certain oil palm genotypes. Such integrative investigation along with classical physiological measurements for phenome analysis was exemplified by a study on pine tree (Pinus radiata) seedlings irradiated with ultraviolet (UV) light to mimic natural incidence of increased UV radiation (Pascual et al., 2017).

\section{Verification of Oil Palm Genetic Improvement Using Omics}

The ultimate aspiration of crop research and development is the observable phenotype i.e. improved characteristics or traits as a result of genome alteration or selective breeding, and increased productivity in terms of yield and quality ensuing enhanced agricultural practices. Going downstream of the genome information within a biological system, the transcripts, proteins and metabolites are the closest features to phenotypic characterisation (Wienkoop et al., 2008). In principal, through this omics passage, the genome information via both conventional breeding and genetic engineering aimed to produce superior oil palm will be transcribed and translated in the organism until it is expressed physically as illustrated in Figure 2. However, the expression of genes into RNA is already prone to internal and external influences

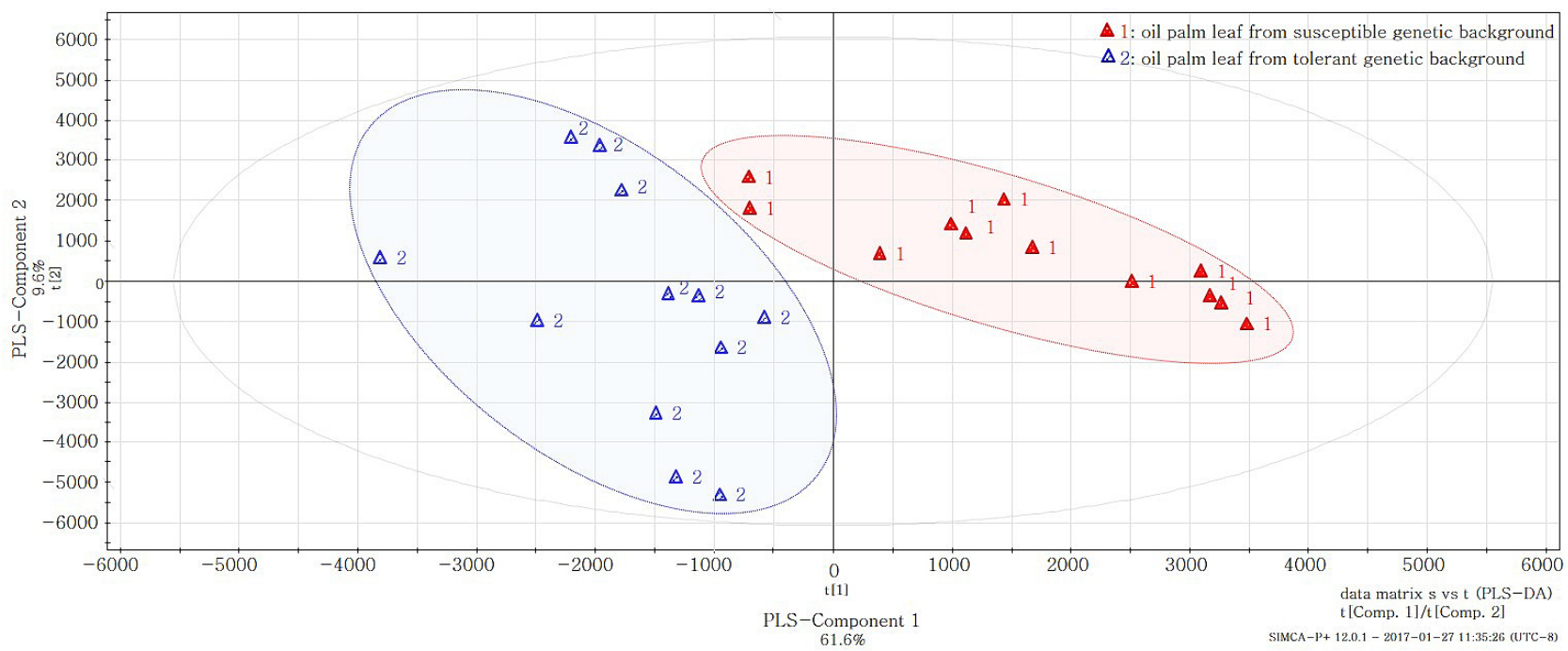

Figure 1. The PLS-DA scores plot of leaf metabolome from oil palm of different susceptibility backgrounds to G. boninense [adapted from Rozali et al. (2017)].

TABLE 3. OIL PALM ROOT AND G. boninense PROTEINS OF DIFFERENT ABUNDANCE

\begin{tabular}{|c|c|c|c|}
\hline Investigations & $\begin{array}{c}\text { Oil palm root } \\
\text { 7-day post-infection }\end{array}$ & $\begin{array}{c}\text { Oil palm root } \\
\text { 14-day post-infection }\end{array}$ & $\begin{array}{c}\text { G. boninense } \\
\text { 3-day post-infection }\end{array}$ \\
\hline References & $\begin{array}{l}\text { Syahanim et al. } \\
\qquad(2013)\end{array}$ & $\begin{array}{l}\text { Al-Obaidi et al. } \\
\text { (2014) }\end{array}$ & $\begin{array}{l}\text { Al-Obaidi et al. } \\
\text { (2017) }\end{array}$ \\
\hline 1 & $\beta$-1,3-glucanase & Malate dehydrogenase & Enolase \\
\hline 2 & $\begin{array}{c}\text { Nucleoside diphosphate } \\
\text { kinase (NDPK) }\end{array}$ & Cysteine synthase & $\begin{array}{l}\text { Alpha-aminoadipate } \\
\text { reductase }\end{array}$ \\
\hline 3 & Glutathione-S-transferase & Enolase & Carboxypeptidase \\
\hline 4 & Early flowering protein 1 & Catechol O-methyltransferase & Dienelactone hydrolase \\
\hline 5 & Ferritin & ATP synthase alpha subunit & Glutamine synthetase \\
\hline 6 & Thioredoxin H2 & Fructokinase & $\begin{array}{l}\text { Guanine nucleotide } \\
\text { binding proteins }\end{array}$ \\
\hline
\end{tabular}




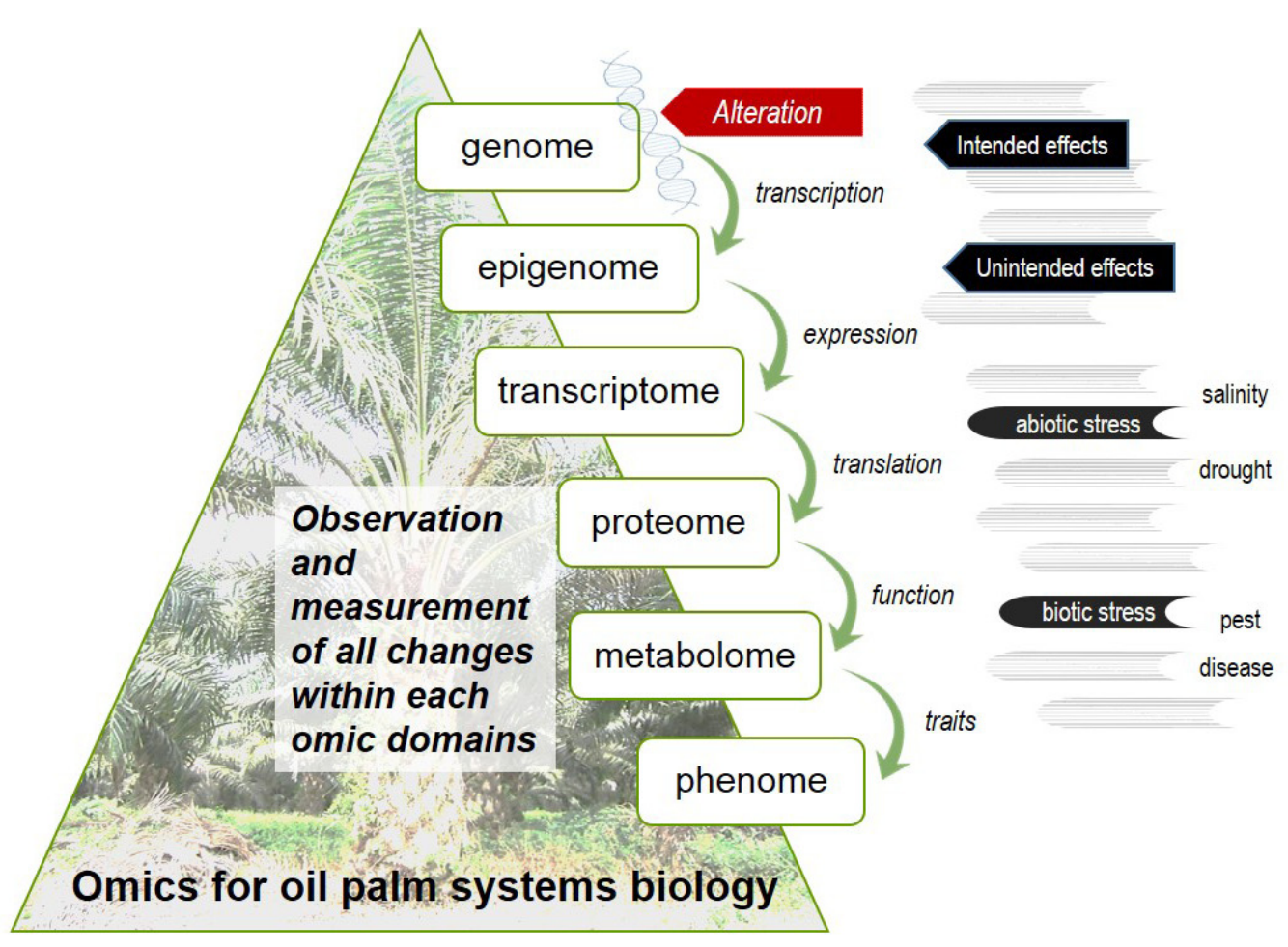

Figure 2. Information flow of integrated omics for crop research.

(Emon, 2016). Based on this premise, uncertainties in unintended effects and risk assessments can be extrapolated using omics mechanistic data gathered from multilevel observations (Van Aggelen et al., 2010).

In general, the productivity of crop is influenced by complex interactions with its surroundings. Unfavourable environmental factors such as challenging soil type and drought may prevent the realisation of expected outcome albeit excellent background of the oil palm. Being contiguous to phenome, the employment of comparative metabolome profiling can help researchers assess the status and responses of oil palm grown in different planting setup. As an example, oil palm leaf metabolome from similar clone showed differentiation according to their planting sites by the content of dopamine and asparagine (Tahir et al., 2016). This demonstrated phenotypic responses that may not be studied effectively by a single discipline, e.g. genome study and may hinder attempts by molecular-assisted breeders and tissue culturists to improve the crop.

The potentials of genetic improvement of oil palm in boosting its performance is tremendous, particularly from the view of sustaining the planet by avoiding the opening of new plantation and deforestation. Precision research and development from the laboratory to field are warranted to accomplish this mission as phenotypic change is a consequence of either or both genetic change or phenotypic plasticity (Merilä and Hendry,
2014). This concern is further aggravated by possible unintended effects due to pleiotropism and could not be gauged with the analysis of a single domain such as metabolomics (Hall and De Maagd, 2014). Such impact can be elucidated by the measurement of at least four types of information to detect differences between the genetically improved crop and its conventional counterpart (Li et al., 2017; Hall and De Maagd, 2014; Kooke and Keurentjes, 2012):

i. Molecular characterisation, e.g. open reading frames, primer pair.

ii. Compositional analysis, e.g. the magnitude of expressions of existing and new proteins, toxicants and allergens.

iii. Agronomicand phenotypiccharacterisation, e.g. statistically significant data of genome inheritance pattern and stability.

iv. Plant-environment interactions (investigation using appropriate replication and controls in space (spatial/synchronic) and in time (temporal/allochronic).

The plant phenotype is highly capricious on a spatiotemporal scale and the comparative measurement should be carried out on specimens that are grown side by side under controlled conditions to elucidate the influence of genetic and environment (Ricroch et al., 2011). Another interesting point to ponder is the equilibrium between the organism investment in growth and defence. In shifting the mechanism of the plant 
towards being tolerance to certain factors, e.g. disease or drought, the components driving its yield could be at expense (Kooke and Keurentjes, 2012). Therefore, the transparent studies from omics research to elucidate the various impact of genetic engineering would certainly increase public acceptance towards genetically modified oil palm.

\section{POST-GENOMICS FUTURE PROSPECTS}

In essence, the advances in genome sequences and genetic engineering techniques have also laid a foundation towards genome editing approach. Genome editing is a new technology that could be applied to allow the modification of oil palm genome in a precise and predictable manner without introducing foreign DNA. The use of genome editing in plant for improvement of various traits was reviewed by Malzahn et al. (2017). This technology also promises a lesser regulatory scrutiny (Arujanan, 2016), as some of regulatory authorities, such as USDA, have decided that some of plants mutated by genome editing, should not be regulated (Wolt et al., 2016).

Genome editing involves the introduction of targeted DNA double-strand breaks (DSB) using engineered nuclease and stimulating DNA repair mechanisms. Zinc finger nuclease (ZFN) and transcription activator-like effector-based nucleases (TALEN) are sequence specific nucleases with DNA binding domain commonly used in genome editing for targeting DNA mutagenesis. In soyabean, TALEN was used for increasing oil yield by targeting FAD2 gene (Haun et al., 2014). However, ZFN and TALEN approaches are not widely adopted for plant regulation due to the difficulty in engineering of modular DNA binding protein, which can potentially increase time and financial investment (Malzahn et al., 2017). A simpler genome editing approach known as clustered regularly interspaced palindromic repeats (CRISPR) has been developed, which allows more effective regulation of targeted gene. The CRISPR/Cas 9 system is an adaptive of bacterial II immune system which requires Cas 9 nuclease to degrade DNA that matches to a single guided RNA (sgRNA) (Malzahn et al., 2017; Song et al., 2016). With the availability of genome and transcriptome data, the sgRNA sequence (19-23 nucleotides) specific to a targeted gene could be precisely designed in efforts to reduce the off-target risks. This system has been widely used in rice for functional genes study (Malzahn et al., 2017). Successful adoption of CRISPR technology was also reported for several other crops with more complex genome such as sorghum, maize, citrus, poplar, tomato, wheat (Jia and Wang, 2014; Jiang et al., 2013; Liang et al., 2014; Svitashev et al., 2015). Recently, CRISPR/Cas 9 has also been looked as a practical approach for editing date palm genome (Sattar et al., 2017).

In Camelina sativa, adoption of CRISPR by editing FAD2 gene has led to an increment of oleic acid from $16 \%$ to over $50 \%$ until T3 generation (Jiang et al., 2017). The stable inheritance of DNA mutation in camelina indicates the suitability of this plant to be used in functional gene studies. Camelina is a hexaploid relative to Arabidopsis, and also is an oilbearing crop. Camelina also has high concentrations of $\alpha$-linolenic acid essential for modifying the LCPUFA (Betancor et al., 2016; 2017). Thus in addition to Arabidopsis, tobacco, and tomato, the use of camelina as an alternative model plant may allow more efficient functional gene study that is beneficial in oil palm genetic transformation.

\section{CONCLUSION}

Genetic manipulation of crop began with selective breeding for domestication and agriculture, marking the beginning of trait establishment of higher yields, pest and disease resistances and faster growth (Emon, 2016). As the demand from human population intensifies, crop performance is bound for rapid improvement with biotechnology as one of the impetus. As human intervention will always be fine-tuned by nature, the precise inference of genetic influence against the environmental effects of biotic and abiotic elements needs to be resolved. Post-genomics oil palm research using omics techniques will allow comprehensive assessment of gene enhancement efforts and further reinforce understanding of oil palm yield and performance traits, developmental stages and effects of agronomic practices.

Genetic engineering will continue to drive significant research towards crop enhancement, with advances in omics technologies that will further reinforce this endeavour. There are challenges to be tackled that limit the beneficial use of omics data such as limited knowledge of metabolic pathways and reproducibility of analysis that could hamper the progress of oil palm improvement. These should be addressed by vigorous and synchronised efforts of researchers from MPOB and the industry. Through these post-genomic researches, the oil palm can be manipulated towards the production of highest possible yield with sustainable practices to fulfil the mission for advancing the Malaysian palm oil industry.

\section{ACKNOWLEDGEMENT}

We wish to thank the Director-General of MPOB for permission to publish this article. We would like to acknowledge members of the Advanced 
Biotechnology and Breeding Centre, MPOB for helpful discussion and technical support. We would also like to extend our appreciation to the staff of the Technology Transgenic, and Proteomics and Metabolomics Groups, MPOB for their kind assistance.

\section{REFERENCES}

ABDULLAH, R; ALIZAH, R; SITI ZUBAIDAH, S and WEE, Y H (1996). Transformation assessments for oil palm improvement. Proc. Natl. Congr. Genet. p. 172-176.

ABDULLAH, R; ZAINAL, A; HENG, W Y; LI, L C; BENG, Y C; PHING, L M; SIRAJUDDIN, S A; PING, W Y S; JOSEPH, J L; JUSOH, S A; MUAD, M R and HUEY, Y L (2005). Immature embryo: a useful tool for oil palm (Elaeis guineensis Jacq.) genetic transformation studies. Electron. J. Biotechnol., 8: 2434.

ABRIZAH, O (2001). Isolation and Characterisation of an Acyl-acyl Carrier Protein (ACP) Thioesterase from Oil Palm. Ph.D thesis. University of Bristol, UK.

ABRIZAH, O; LAZARUS, C M; FRASER, T and STOBART, A K (2000). Cloning of palmitoyl-ACP thioesterase from oil palm. Biochem. Soc. Trans., 28: 619-622.

ALIZADEH, F;ABDULLAH, SN A; KHODAVANDI, A; ABDULLAH, F; YUSUF, U K and CHONG, P P (2011). Differential expression of oil palm pathology genes during interactions with Ganoderma boninense and Trichoderma harzianum. J. Plant Physiol., 168: 1106-1113.

AL-OBAIDI, J R; YUSMIN, M D; NURHANANI, R; JAYAPALAN, J J; TEY, C C; NORMAHNANI, M N; SARNI, M J; OTHMAN, R Y and ONN, H (2014). Identification of proteins of altered abundance in oil palm infected with Ganoderma boninense. International J. Molecular Science, 15: 5175-5192.

AL-OBAIDI, J R; HUSSIN, S N I S; SAIDI, N B; RAHMAD, N and IDRIS, A S (2017). Comparative proteomic analysis of Ganoderma species during in vitro interaction with oil palm root. Physiol. Mol. Plant Pathol., 99: 16-24.

ARUJANAN, M (2016). Development of agricultural biotechnology in Malaysia in comparison to global status. The Planter, 92(1087): 689-697.

ASEMOTA, O; SAN, C T and SHAH, F H (2004). Isolation of kernel oleoyl-ACP thioesterase gene from oil palm Elaeis guineensis Jacq. African J. Biotechnol., 3(3): 199-201.
AS'WAD, A W M; SARIAH, M; PATERSON, R R M; ZAINAL ABIDIN, M A and LIMA, N (2011). Ergosterol analyses of oil palm seedlings and plants infected with Ganoderma. Crop Prot., 30: 1438-1442.

BAHARIAH, B; PARVEEZ, G K A and KHALID, N (2012). Determination of optimal concentration of mannose as a selection agent for selecting transformed oil palm cells using the phosphomannose isomerase ( $\mathrm{pmi}$ ) gene as the positive selectable marker. J. Oil Palm Res. Vol. 24: 1250-1259.

BAHARIAH, B; PARVEEZ, G K A; MASANI, M Y A; MASURA, S S; KHALID, N and OTHMAN, R Y (2013). Biolistic transformation of oil palm using the phosphomannose isomerase ( $\mathrm{pmi}$ ) gene as a positive selectable marker. Biocatal. Agri. Biotech., 2: 295-304.

BAHARIAH, B; MASANI, M Y A; RASID, O A and PARVEEZ, G K A (2017). Construction of a vector containing hygromycin (HPT) gene driven by double 35S (2XCaMV35S) promoter for oil palm transformation. J. Oil Palm Res. Vol. 29(2): 180-188.

BERANOVÁ, M; RAKAOUSKÝ, S; AVROVÁ, $Z$ and SKALIKÝ, T (2008). Sonication assisted Agrobacterium-mediated transformation enhances the transformation efficiency in flax Linum usitatissimum L). Plant Cell Tiss. Organ Cult., 94: 253259.

BETANCOR, M B; LI, K; SPRAGUE, M; BARDAL, T; SAYONARA, O; USHER, S; HAN, L; MÅSØVAL, K; TORRISSEN, O; NAPIER, J A; TOCHER, D R and OLSEN, R E (2017). An oil containing EPA and DHA from transgenic Camelina sativa to replace marine fish oil in feeds for Atlantic salmon (Salmon salar L.): effects on intestinal transcriptome, histology, tissue fatty acids profiles and plasma biochemistry. PLoS One. DOI: 10.1371/journal.pone.0175415.

BETANCOR, M B; SPRAGUE, M; SAYANOVA, O; USHER, S; METOCHIS, $C$ and CAMPBELL, P J (2016). Nutritional evaluation of an EPA-DHA oil from transgenic Camelina sativa in feeds for postsmolt Atlantic salmon (Salmo salar L.). PLoS One. DOI: 10.1371/ journal.pone.0159934.

BHORE, S J (2013). Sustainable oil-palm cultivation: we need to use 'gene technology' to boost palm-oil production. Gene Technology. DOI:10.4172/23296682.1000e105.

BHORE, S J and SHAH, F H (2012). Genetic transformation of American oil palm (Elaeis oleifera) immature zygotic embryos with antisense palmitoylacyl carrier thioesterase (PATE) gene. World Appl. Sci., 16(3): 362-369. 
BIRCH, R G (1997). Plant transformation: problems and strategies for practical application. Annu. Rev. Plant Physiol. Plant Mol. Biol., 48: 297-326.

CHAN, P L; SITI NOR AKMAR, A and ROOHAIDA, O (2008). Light-harvesting chlorophyll a/b binding protein (Lhcb) promoter for targeting specific expression in oil palm leaves. J. Oil Palm Res. Special Issue on Malaysia-MIT Biotechnology Partnership Programme: Vol. 2 - Oil Palm Metabolic Engineering: 21-29.

CHAN, K L; ROSLI, R; TATARINOVA, T; HOGAN, M; FIRDAUS-RAIH, M and LOW, E T L (2016). Gene prediction pipeline for genomes using self-trained gene models and transcriptomic data. bioRxiv, 03818.

CHONG, K L; KANNIAH, K D; POHL, C and TAN, K P (2017). A review of remote sensing applications for oil palm studies. Geo-spatial Information Science, 20 (2): 184-200.

CHOWDHURY, M K U; PARVEEZ, G K A and NORIHAN, MS (1997). Evaluation of five promoters for use in transformation of oil palm (Elaies guineensis Jacq.). Plant Cell Rep., 16: 277-281.

CHOO, Y M (2012). Malaysia: Economic transformation advances oil palm industry. https: / / www.aocs.org/stay-informed/readinform / featured-articles / malaysia-economic transformation-advances-oil-palm-industryseptember-2012, accessed in September 2017.

CHENG, M; HU, T; LAYTON, J; LIU, C N and FRY, J E (2003). Desiccation of plant tissues postAgrobacterium infection enhances T-DNA delivery and increase stable transformation efficiency in wheat. In vitro Cell. Dev. Biol., 39: 595-604.

DENNEHEY, B K; PETERSON, W L; ORDSANTINO, C; PAJEAU, $M$ and AMSTRONG, C L (1994). Comparison of selective agents for use with the selectable marker gene bar in maize transformation. Plant Cell Tiss. Organ Cult., 36: 1-7.

DUAN, C G; WANG, C H and GUO, H S (2012). Application of RNA silencing to plant disease resistance. Silence, 3: 5 DOI:10.1186/1758-907X-3-5.

DUSSERT, S; GUERIN, C; ANDERSSON, M; JOËT, T; TRANBARGER, T J; PIZOT, M; SARAH, G; OMORE, A; DURAND-GASSELIN, T and MORCILLO, F (2013). Comparative transcriptome analysis of three oil palm fruit and seed tissues that differ in oil content and fatty acid composition. Plant Physiol., 162: 1337-1358.

DZULKAFLI, S B; ABRIZAH, O; LAU, B Y C, SYAHANIM, S; IDRIS, A $S$ and RAMLI, U S (2016).
Optimization of protein extraction from Ganoderma boninense for SDS PAGE analysis. Transactions of Persatuan Genetik Malaysia, 3: 193-197.

EMON, J M V (2016). The omics revolution in agricultural research. J. Agric. Food Chem., 64 (1): 3644 .

EUSTICE, D C and WILHEIM, J M (1984). Mechanisms of action of aminoglycoside antibiotics in eukaryotic protein synthesis. Antimicrob. Agents Chemother., 26: 53-60.

FADEEV, V S; BLINKOVA, O V and GAPONENKO, A K (2006). Optimization of biological and physical parameters for biolistic genetic transformation of common wheat (Triticum aestivum L.) using a particle inflow gun. Russian J., 42(4): 402-411.

FAKHRANA, I N; LIM, F H; RASID, O A; IDRIS, A $S$ and PARVEEZ, G K A (2011). Isolation of partiallength Laccase cDNA from Ganoderma boninense. Proc. of the PIPOC 2011 International Palm Oil Congress. MPOB, Bangi. p. 156-163.

FAKHRANA, I N; RASID, O A and PARVEEZ, G K A (2015). Effective concentration of hygromycin for selecting transformed oil palm. Proc. of the PIPOC 2015 International Palm Oil Congress. MPOB, Bangi. p. $473-477$.

FROMM, M E; MORRISH, F; AMSTRONG, C; WILLIAMS, R; THOMAS, J and KLEIN, T M (1990). Inheritance and expression of chimeric genes in progeny of transgenic maize plants. Bio/Technology, 8: 833-839.

FUAD, F A A; ISMAIL, I; SIDIK, N M; ZAIN, C R C $M$ and ABDULLAH, R (2008). Super binary vector system enhanced transformation frequency and expression level of polyhydroxyvalerate gene in oil palm immature embryo. Asian J. Plant Sci., 7(6): 526535.

GATICA, A M; ARRIETA, G and ESPINOZA, A M (2009). Optimization of coffee (Coffea arabica) transformation parameters using uidA and hpt genes: effect of osmotic pre-treatment, helium pressure and target distance. Rev. Biol. Trop. Int. J. Trop. Biol., 57: 151-160.

GANDHI, R; MAHESWARI, S C and KHURANA, $P$ (1999). Transient gus expression and influence of promoters on foreign gene expression in Arabidopsis thaliana. In vitro Cell. Dev. Biol. Plant, 35: 232-237.

GRAEF, G; LAVALLEE, B J; TENOPIR, P; TAT, M E; SCHWEIGER, B J; KINNEY, A J; VAN GERPEN, J and CLEMENTE, T E (2009). A high oleic acid and 
low palmitic acid soybean: agronomic performance and evaluation as a feedstock for biodiesel. Plant Biotechnol. J., 7: 411-421.

HALL, R D and DE MAAGD, R A (2014). Plant metabolomics is not ripe for environmental risk assessment. Trends Biotechnol., 32 (8): 391-392.

HIEI, Y and KOMARI, T (2006). Improved protocols for transformation of Indica rice mediated by Agrobacterium tumefaciens. Plant Cell Tiss. Organ Cult., 85: 271-283.

HANIN, A N; MASANI, M Y A and PARVEEZ, G K A (2016). Evaluation of oil palm leaf-specific promoter (LSP1) activity for expressing $p h b$ genes in Arabidopsis thaliana. J. Oil Palm Res. Vol. 28(1): 1-9.

HASSAN, H; LAU, B Y C and RAMLI, U S (2014). Extraction methods for analysis of oil palm leaf and root proteins by two-dimensional gel electrophoresis. J. Oil Palm Res. Vol. 26(1): 54-61.

HASSAN, H; TAHIR, N I and RAMLI, U S (2016). Proteome and metabolome assessment of oil palm fruit development for advanced breeding perspective. Transactions of Persatuan Genetik Malaysia, 3: 199-204.

HAUN, W; COFFMAN, A; CLASEN, B M; DEMOREST, Z L; LOWY, A; RAY, E; RETTERATH, A; STODDARD, T; JUILLERAT, A; CEDRONE, F; MATHIS, L; VOYTAS, D F and ZHANG, F (2014). Improved soybean oil quality by targeted mutagenesis of the fatty acid desaturase 2 gene family. Plant Biotechnol. J., 12: 934-940.

IZAWATI, A M D; MASANI, A M Y; ISMANIZAN, I and PARVEEZ, G K A (2015). Evaluation on the effectiveness of 2-deoxyglucose-6-phosphate $\left(D^{\mathrm{R}} 1\right)$ gene as a selectable marker for oil palm (Elaeis guineensis Jacq.) embryogenic calli transformation mediated by Agrobacterium tumefaciens. Front. Plant Sci., 6: 727. DOI :10.3389/ fpls.2015.00727.

IZAWATI, A M D; MASANI, A M Y; PARVEEZ, G $\mathrm{K} A$ and ISMANIZAN, I (2017a). 2-deoxyglucose selection system for Agrobacterium-mediated transformation of Solanum lycorpension and Nicotiana tabacum plants. Australian J. Crop Sci., 7: 813-820.

IZAWATI, A M D; MASANI, A M Y; RASID, O A and PARVEEZ, G K A (2017b). Evaluation of transient $g f p$ gene expression in Dura embryogenic calli by biolistic-mediated transformation. Proc. of the PIPOC 2017 International Palm Oil Congress. MPOB, Bangi. p. 61-63.
IZAWATI, A M D; PARVEEZ, G K A and ISMAIL, I (2012). Optimisation of 2-deoxyglucose concentration for identifying the sensitivity level for oil palm embryogenic calli. J. Oil Palm Res. Vol. 24: 1296-1302.

JIANG, W Z; ZHOU, H B; BI, H H; FROMM, M; YANG, B and WEEKS, D P (2013). Demonstration of CRISPR/Cas9/sgRNA-mediated targeted gene modification in Arabidopsis, tobacco, sorghum and rice. Nucleic Acids Res., 41: 1-12.

JIANG, W Z; HENRY, I M; LYNAGH, P G; COMAI, L; CAHOON, E B and WEEKS, D P (2017). Significant enhancement of fatty acid composition in seeds of the allohexaploid, Camelina sativa, using CRISPR/ Cas9 gene editing. Plant Biotechnol. J., 15: 648-657.

JIA, H G and WANG, N (2014). Targeted genome editing of sweet orange using Cas9/sgRNA. PLoS One, 9(4): e93806. DOI:10.1371/journal. pone.0093806.

KOOKE, R and KEURENTJES, J J B (2012). Multidimensional regulation of metabolic networks shaping plant development and performance. J. Experimental Botany, 63: 3353-3365.

KNUTZON, D S; THOMPSON, G A; RADKE, S E; JOHNSON, W B; KNAUF, V C and KRIDL, J C (1992). Modification of Brassica seed oil by antisense expression of a stearoyl-acyl carrier protein desaturase gene. Proc. Natl. Acad. Sci. USA, 89: 26242628.

KUSHAIRI, A (2017). Malaysian palm oil performance 2016 and future prospects for 2017. http: / / www.mpob.gov.my / images / stories / pdf/2017/2017_Dr.KushairiPALMEROS2017.pdf, accessed in September 2017.

LASSNER, M W; LARDIZABAL, $\mathrm{K}$ and METZ, J G (1996). A jojoba $\beta$-ketoacyl-CoA synthase cDNA complements the canola fatty acid elongation mutation in transgenic plants. The Plant Cell, 8: 281292.

LAU, B Y C; DEB CHOUDHURY, S; MORTON, J D; CLERENS, S; DYER, J M and RAMLI, U S (2015). Method developments to extract proteins from oil palm chromoplast for proteomic analysis. SpringerPlus, 4(791): 1-13.

LELONG, C C D; ROGER, J M; BRÉGAND, S; DUBERTRET, F; LANORE, M; SITORUS, N A; RAHARJO, D A and CALIMAN, J P (2010). Evaluation of oil-palm fungal disease infestation with canopy hyperspectral reflectance data. Sensors, 10: 734-747. 
LI, R; QUAN, S; YAN, X; BISWAS, S; ZHANG, D and SHI, J (2017). Molecular characterization of genetically-modified crops: Challenges and strategies. Biotechnol. Adv. 35(2): 302-309.

LIANG, Z; ZHANG, K; CHEN, K L and GAO, C $X$ (2014). Targeted mutagenesis in Zea mays using TALENs and the CRISPR/Cas system, J. Genet. Genomics, 41: 63-68.

LIM, F H; FAKHRANA, I N; RASID, O A; IDRIS, A S; PARVEEZ, G K A; HO, C L and SHAHARUDDIN, $\mathrm{N} A$ (2014). Isolation and selection of references genes for Ganoderma boninense gene expression study using quantitative real-time PCR (qPCR). J. Oil Palm Res. Vol. 26: 170-181.

LIM, F H; FAKHRANA, I N; RASID, O A; IDRIS, A S; PARVEEZ, G K A; HO, C L and SHAHARUDDIN, N A (2016). Molecular cloning and expression analysis of Ganoderma boninense Cyclophilins at different growth and infection stages. Physiol. Mol. Plant Pathol. DOI:10.1016/j.pmpp.2016.05.005.

LJUBEŠIĆ, N; WRISCHER, M and DEVIDÉ, Z (1991). Chromoplast - the last stages in plastid development. Int. J. Dev. Biol., 35: 251-258.

LIU, Q; SING, S and GREEN, A (2000). Genetic modification of cotton seed oil using inverted repeat gene silencing techniques. Biochem. Soc. Trans., 28: 927-929.

LOEI, H; LIM, J; TAN, M; LIM, T K; LIN, Q S; CHEW, $\mathrm{F} \mathrm{T}$; KULAVEERASINGAM, $\mathrm{H}$ and CHUNG, M C M (2013). Proteomic analysis of the oil palm fruit mesocarp reveals elevated oxidative phosphorylation activity is critical for increased storage oil production. J. Proteome Res., 12(11): 50965109.

LOW, E T L; SINGH, R; NOOKIAH, R; ONGABDULLAH, M; OOI, L C L; LAKEY, N D; SMITH, S W; ORDWAY, J M and SAMBANTHAMURTHI, R (2016). New frontiers for the oil palm industry through genome technology. The Planter, 92(1087): 701-710.

MAJID, N A and PARVEEZ, G KA (2007). Evaluation of green fluorescence protein (GFP) as a selectable marker for oil palm transformation via transient expression. Asia Pac. J. Mol. Bio. Biotech., 15: 1-8.

MAJID, N A and PARVEEZ, G K A (2016). Regeneration of transgenic oil palm carrying GFP gene used as a visual selectable marker. J. Oil Palm Res. Vol. 28(4): 415-430.
MALONE, J H and OLIVER, B (2011). Microarrays, deep sequencing and the true measure of the transcriptome. BMC Biology, 9: 34.

MALZAHN, A; LOWDER, L and QI, Y (2017). Plant genome editing with TALEN and CRISPR. Cell Biosci., 7: 21.

MANAF, M A A; ABRIZAH, O and RAMLI, U S (2005). Characterization of genes encoding key enzymes in oil synthesis in the oil palm. Proc. of the PIPOC 2005 International Palm Oil Congress. MPOB, Bangi. p. 583-606.

MANAF, M A A; IZAWATI, A M D; ZUBAIDAH, R; MASANI, A M Y; SAFIZA, M; LIM, F H; NURNIWALIS, A W; RASID, O A and PARVEEZ, G K A (2017). Biotechnology for diversification and improved resilience of the oil palm. The Planter, 93(1093): 237-249.

MANIMARAN, P; RAVIKUMAR, G; RAGHURAMIREDDY, M; JAIN, S; BHASKARRAO, T; MANGRAUTHIAS, K; SUNDARAM, $\mathrm{R} \mathrm{M}$; RAVICHANDRAN, $\mathrm{S}$ and BALACHANDRAN, $\mathrm{S} \mathrm{M}$ (2013). Infection of early and young callus tissues of indica rice BPT 5204 enhances regeneration and transformation efficiency. Rice Sci., 20(6): 415-426.

MASANI, M Y A; PARVEEZ, G K A; IZAWATI, A M D; LAN, C P and SITI NOR AKMAR, A (2009). Construction of PHB and PHBV multiple-gene vectors driven by an oil palm leaf-specific promoter. Plasmid, 62: 191-200.

MASANI, A M Y; NOLL, G A; PARVEEZ, G K A; SAMBANTHAMURTHI, R and PRÜFER, D (2014). Efficient transformation of oil palm protoplasts by PEG-mediated transfection and DNA microinjection. PLoS One. DOI:10.1371/journal.pone.0096831.

MASANI, M Y A; NOLL, G; PARVEEZ, G K $\mathrm{A}$; SAMBANTHAMURTHI, $\mathrm{R}$ and PRÜFER, $\mathrm{D}$ (2013). Regeneration of viable oil palm plants from protoplasts by optimizing media components, growth regulators and cultivation procedures. Plant Sci., 210: 118-127.

MASLI, D I A; KADIR, A P G and YUNUS, A M M (2009). Transformation of oil palm using Agrobacterium tumefaciens. J. Oil Palm Res. Vol. 21: 643-652.

MASURA, S S; PARVEEZ, G K A and LOW, E T L (2011). Isolation and characterization of an oil palm constitutive promoter from a translationally control tumor protein (TCTP) gene. Plant Physiol. Biochem., 40: 701-708. 
MASURA, S S; PARVEEZ, G K A and ISMANIZAN, I (2010). Isolation and characterization of oil palm constitutive promoter derived from ubiquitin extension protein (uep1) gene. New Biotechnology, 27: 289-299.

MASURA, S S; RASID, O A; PARVEEZ, G K A; NURFAHISZA, A R and MASANI, A M Y (2017). Development of a selection scheme for transformation oil palm immature calli using biolistics. Proc. of the PIPOC 2017 International Palm Oil Congress. MPOB, Bangi. p. 82-85.

MERILÄ, J and HENDRY, A P (2014). Climate change, adaptation, and phenotypic plasticity: the problem and the evidence. Evol. Appl., 7(1): 1-14.

MOCHIDA, K and SHINOZAKI, K (2011). Advances in omics and bioinformatics tools for systems analyses of plant functions. Plant Cell Physiol., 52 (12): 2017-2038.

MONTOYA, C; LOPES, R; FLORI, A; CROS, D; CUELLAR, T; SUMMO, M; ESPEOUT, S; RIVALLAN, R; RISTERUCCI, A M; BITTENCOURT, D; ZAMBRANO, J R; ALARCON, G W H; VILLENEUVE, P; PINA, M; NOUY, B; AMBLARD, P; RITTER, E; LEROY, Y and BILLOTE, N (2013). Quantitative trait loci (QTLs) analysis of palm oil fatty acid composition in an interspecific pseudobackross from Elaies oleifera (H.B.K) Cortés and oil palm (Elaies guineensis Jacq.). Tree Genetics and Genomes. DOI: 10.1007/S11295-013-0629-5.

MURPHY, D J (2014). The future of oil palm as a major global crop: opportunities and challengers. J. Oil Palm Res. Vol. 26: 1-24.

NEOH, B K; TEH, H F; NG, T L M; TIONG, S H; THANG, YM;ERSAD, MA;MOHAMED, M; CHEW, F T; KULAVEERASINGAM, H and APPLETON, D R (2013). Profiling of metabolites in oil palm mesocarp at different stages of oil biosynthesis. J. Agric. Food Chem., 61(8): 1920-1927.

NURAZAH, Z; IDRIS, A S; KUSHAIRI, A; AMIRUDDIN, M D; ABRIZAH, O and RAMLI, U $S$ (2017). Metabolomics unravel differences between Cameroon dura and Deli dura oil palm (Elaeis guineensis Jacq.) genetic backgrounds against basal stem rot. J. Oil Palm Res. Vol. 29 (2): 227-241.

NURAZAH, Z; IDRIS, A S; KUSHAIRI, A and RAMLI, U S (2013). Metabolite profiling of oil palm towards understanding basal stem rot (BSR) disease. J. Oil Palm Res. Vol. 25 (1): 58-71.

NURFAHISZA, A R; RAFIQAH, M A; MASANI, MY A; HANIN, A N; RASID, O A; PARVEEZ, G K A and
ISMAIL, I (2014). Molecular analysis of transgenic oil palm to detect the presence of transgenes. J. Oil Palm Res. Vol. 26: 73-80.

NURFAHISZA, A R; RAFIQAH, M A; PARVEEZ, G K A and RASID, O A (2016). Comparison of the effectiveness of basta, bialaphos and glufosinate ammonium for selecting transformed oil palm tissues. J. Oil Palm Res. Vol. 28(3): 247-255.

NURNIWALIS, A W; SUHAIMI, N; SITI NOR AKMAR, A; AMINAH, $S$ and MOHAMAD ARIF, M A (2008). Gene discovery via expressed sequence tags from the oil palm (Elaeis guineensis Jacq.) mesocarp. J. Oil Palm Res. Vol. 2: 87-96.

NURNIWALIS, A W; ZUBAIDAH, R; SITI NOR AKMAR, A; ZULKIFLI, H; MOHAMAD ARIF, M A; MASSAWE, F J; CHAN, K L and PARVEEZ, G K A (2015). Genomic structure and characterization of a lipase class 3 gene and promoter from oil palm. Biologia Plantarum, 59(2): 227-236.

NUSAIBAH, S A; SITI NOR AKMAR, A; IDRIS, A S; SARIAH, $M$ and MOHAMAD PAUZI, Z (2016). Involvement of metabolites in early defense mechanism of oil palm (Elaeis guineensis Jacq.) against Ganoderma disease. Plant Physiol. Biochem., 109: 156-165.

OMAR, W S W; WILLIS, L B; RHA, C; SINSKEY, A J; RAMLI, U S; YUNUS, A M M; PARVEEZ, G K A and SAMBANTHAMURTHI, R (2008). Isolation and utilization of acetyl-CoA carboxylase from oil palm. J. Oil Palm Res. Special Issue on Malaysia-MIT Biotechnology Partnership Programme: Vol. 2 - Oil Palm Metabolic Engineering: 97-107.

ONG-ABDULLAH, M; ORDWAY, J M; JIANG, N; OOI, S E; KOK, S Y; SARPAN, N; AZIMI, N; HASHIM, A T; ISHAK, Z; ROSLI, S K; MALIKE, F A; BAKAR, N A; MARJUNI M; ABDULLAH, N; YAAKUB, Z; AMIRUDDIN, M D; NOOKIAH, R; SINGH, R; LOW, T; CHAN, K L; AZIZI, N; SMITH, S W; BACHER, B; BUDIMAN, M A; VAN BRUNT, A; WISCHMEYER, C; BEIL, M; HOGAN, M; LAKEY, $\mathrm{N}$; LIM, C C; ARULANDOO, X; WONG, C K; CHOO, C N; WONG, W C; KWAN, Y Y; ALWEE, S $S$; SAMBANTHAMURTHI, R and MARTIENSSEN, R A (2015). Loss of Karma transposon methylation underlies the mantled somaclonal variant of oil palm. Nature, 525: 533-537.

OOI, T E K; YEAP, W C; DAIM, L D J; NG, B Z; LEE, F C; OTHMAN, A M; APPLETON D R; CHEW, F $T$ and KULAVEERASINGAM, H (2015). Differential abundance analysis of mesocarp protein from high- and low-yielding oil palms associates non-oil biosynthetic enzymes to lipid biosynthesis. Proteome Science, 13 (28): 1-15. 
PARVEEZ, G K A (1998). Optimization of Parameters Involved in Transformation of Oil Palm Using the Biolistic Method. Ph.D thesis. Universiti Putra Malaysia.

PARVEEZ, G K A (2000). Production of transgenic oil palm (Elaeis guineensis Jacq.) using biolistic techniques. Molecular Biology of Woody Plants (Jain, S $\mathrm{M}$ and Minocha, S C eds.). Vol. 2. Kluwer Academic Publishers, Netherlands, p. 327-350.

PARVEEZ, G K A; ABRIZAH, O; NURHAFIZAH, R and BAHARIAH, B (2010). Functional analysis of oil palm palmitoyl-acyl-ACP thioesterase (FatB) gene via down-regulation in a model plant: Arabidopsis thaliana. J. Oil Palm Res. Vol. 22: 803-813.

PARVEEZ, G K A; RASID, O A; MASANI, A M Y and SAMBANTHAMURTHI, R (2015a). Biotechnology of oil palm: strategies towards manipulation of lipid content and composition. Plant Cell Rep., 34: 533-543.

PARVEEZ, G K A; BAHARIAH, B; HANIN N A; MASANI, A M Y; RASID, O A; TARMIZI, A $\mathrm{H}$ and ISHAK, Z (2015b). Production of polyhydroxybutyrate in oil palm (Elaeis guineensis Jacq.) mediated by microprojectile bombardment of PHB biosynthesis genes into embryogenic calli. Front. Plant Sci. DOI: 10.3389/fpls.2015.00598.

PARVEEZ, G K A; CHOWDHURY, M K U and SALEH, N M (1996). Determination of minimal inhibitory concentration of selection agents for oil palm (Elaeis guineensis Jacq.) transformation. Asia Pac. J. Mol. Biol. Biotechnol., 4: 219-228.

PARVEEZ, G K A; CHOWDHURY, M K U and SALEH, N M (1997). Physical parameters affecting transient GUS gene expression in oil palm using the biolistics device. Ind. Crops Prod., 6: 41-50.

PARVEEZ, G K A; CHOWDHURY, M K U and SALEH, N M (1998). Biological parameters affecting transient GUS gene expression in oil palm embryogenic calli via microprojectile bombardment. Ind. Crops Prod., 8: 17-27.

PARVEEZ, G K A and MAJID, N A (2008). Factors affecting green fluorescence protein (GFP) gene expression in oil palm after microprojectile bombardment mediated transformation. J. Oil Palm Res. Vol. 20: 495-507.

PARVEEZ G K A; MAJID, N A; ALIZAH, Z and OMAR, A R (2007). Determination of minimal inhibitory concentration of selection agents for selecting transformed immature embryos of oil palm. Asia Pacific J. Mol. Biol. Biotechnol., 15: 133146.
PARVEEZ, G K A; RASID, O A; MASANI, A M Y; HALIZA, H F; MAJID, N A; KHUSHAIRI, A; TARMIZI, A H and ZAMZURI, I (2003). Transgenic oil palm: where are we? Advanced Research on Plant Lipids (Murata ed.). Academic Publishers. p. 415418.

PARVEEZ, G K A; RASID, O A; ZAINAL, A; MASRI, M M; MAJID, N A; FADILLAH, H H; YUNUS, A M $\mathrm{M}$ and CHEAH, S C (2000). Transgenic oil palm: production and projection. Biochemistry Society Transactions, 28(6): 969-972.

PASCUAL, J; CAÑAL, M J; ESCANDÓN, M; MEIJÓN, M; WECKWERTH, W and VALLEDOR, L (2017). Integrated physiological, proteomic, and metabolomic analysis of ultra violet (UV) stress responses and adaptation mechanisms in Pinus radiata. Mol. Cell Proteomic, 16: 485-501.

PATHAK, M R and HAMZAH, R Y (2008). An effective method of sonication-assisted Agrobacterium-mediated transformation of chickpeas. Plant Cell Tiss. Organ Cult., 93: 65-71.

PRIYA, A M; PANDIAN, S K and MANIKANDAN, $R$ (2012). The effect of different antibiotics from elimination of Agrobacterium and high frequency Agrobacterium-mediated transformation of Indica rice (Oryza sativa L.). Czech J. Genet. Plant Breed., 48(3): 120-130.

QU, J; MAO, H Z; CHEN, W; GAO,S Q; BAI, Y N; SUN, Y W; GENG, Y F and YE, J (2012). Development of marker-free transgenic Jatropha plants with increased levels of seed oleic acid. Biotechnol. Biofuels, 5: 10.

RAMLI, U S and SAMBANTHAMURTHI, R (1996). $\beta$-Ketoacyl-ACP synthase II in the oil palm (Elaeis guineensis Jacq.) mesocarp. Physiology, Biochemistry and Molecular Biology of Plant Lipids (Williams, J P; Khan, U M and Lem, N W eds.). Kluwer Academic Publishers. Toronto, p. 69-71.

RAMLI, U S; SAMBANTHAMURTHI, R; RASID, O A; PARVEEZ, G K A; MANAF, M A A; ABRIZAH, O; YUNUS, A M M; CHEAH, S C; ALWEE, S S R S; SITI NOR AKMAR, A and BASRI, M W (2012). The isolation and characterisation of oil palm (Elaeis guineensis Jacq.) $\beta$-ketoacyl-acyl carrier protein (ACP) synthase (KAS) II cDNA. J. Oil Palm Res. Vol. 24: 1480-1491.

RAMLI, U S; LAU, B Y C; TAHIR, N I; SYAHANIM, S; HASSAN, H; NURAZAH, Z; ROZALI, N L; DZULKAFLI, S B; NUR'AIN, M I and ABRIZAH, O (2016). Proteomics and metabolomics: spearheading 
oil palm improvement and sustainability. The Planter, 92 (1087): 727-737.

RASID, O A and SHAH, F H (1996). The isolation, characterization and sequencing of cDNA clones coding for strearoyl-ACP desaturase gene from oil palm (Elaeis guineensis). Proc. of PORIM International Palm Oil Congress. PORIM, Bangi. p. 575-578.

RASID, O A; WAN NUR SYUHADA, W S; HANIN, A N; MASURA, S S; ZULQARNAIN, M; $\mathrm{HO}, \mathrm{C}$ L; SAMBANTHAMURTHI, $\mathrm{R}$ and SUHAIMI, N (2008). RT-PCR amplification and cloning of partial DNA sequence coding for oil palm (Elaeis oleifera) phytoene synthase gene. Asia Pac. J. Mol. Biol. Biotechnol., 16(1): 17-24.

RASID, O A; WAN NUR SYUHADA, W $S$; HANIN, N A; MASURA, S S and PARVEEZ, G K A (2014a). Molecular cloning and regulation of oil palm (E. guineensis Jacq.) phytoene desaturase in developing mesocarp tissues. J. Oil Palm Res. Vol. 26: $37-46$

RASID, O A; LIM, F H; NOOR AZMI, S; FAKHRANA, I N; IDRIS, A $S$ and PARVEEZ, G K A (2014b). Isolation of a partial cDNA clone coding for Ganoderma boninense pde. J. Oil Palm Res. Vol. 26: 272-276.

RECH, E L; VIANNA, G R and ARAGÃO, F J L (2008). High-efficiency transformation by biolistics of soybean, common bean and cotton transgenic plants. Nature Protocols, 3: 410-418.

RIBAS, A F; DECHAMP, E; CHAMPION, A; BERTRAND, B; COMBES, M C; JEAN-LUC VERDEIL, J L; LAPEYRE, F; LASHERMES, P and ETIENNE, H (2011). Agrobacterium-mediated genetic transformation of Coffea arabica (L.) is greatly enhanced by using established embryogenic callus cultures. BMC Plant Biol., 11: 92. DOI: 10.1186/14712229-11-92.

RICROCH, A E; BERGÉ, J B and KUNTZ, M (2011). Evaluation of genetically engineered crops using transcriptomic, proteomic and metabolomics profiling techniques. Plant Physiol., 155: 1752-1761.

RIVAL, A and JALIGOT, E (2010). Oil palm biotechnologies are definitely out of infancy. Agronomie-Environement, 17: 368-374.

ROZALI, N L; YARMO, M A; IDRIS, A S; KUSHAIRI, A and RAMLI, US (2017). Metabolomics differentiation of oil palm (Elaeis guineensis Jacq.) spear leaf with contrasting susceptibility to Ganoderma boninense. Plant Omics, 10: 45-52.
RUIZ-LOPEZ, N; HASLAM, R P; USHER, S L; NAPIER, J A and SAYANOVA, O (2013). Reconstitution of EPA and DHA biosynthesis in Arabidopsis: iterative metabolic engineering for the synthesis of $n-3$ LC-PUFAs in transgenic plants. Metab. Eng., 17: 30-41.

SAFIZA, M; ABRIZAH, O; SITI NOR AKMAR, A and MOHAMAD ARIF, A M (2009a). Functional characterization of oil palm stearoyl-ACP desaturase by overexpression in wild-type Arabidopsis and complementation of fab2 mutant. Proc. of the PIPOC 2009 International Palm Oil Congress. MPOB, Bangi. p. 1229-1243.

SAFIZA, M; MOHAMAD ARIF, A $M$ and ABRIZAH, O (2009b). Functional lysophosphatidyl acyltransferases. Proc. of the PIPOC 2009 International Palm Oil Congress. MPOB, Bangi. p. 1244-1253.

SAFIZA, M; ANITA, J; MOHAMAD ARIF, A M and FAZLIZA, M A (2015). Differentially expressed genes in G. boninense naturally-infected palms. Proc. of the PIPOC 2015 International Palm Oil Congress. MPOB, Bangi. p. 617-621.

SAMBANTHAMURTHI, R (2016). Sowing the seeds of revolution. The Planter, 92 (1087): 685.

SAMBANTHAMURTHI, R; RAJINDER, $S$; PARVEEZ, G K A; ONG-ABDULLAH, $M$ and KUSHAIRI, A (2009). Opportunities for oil palm via breeding and biotechnology. Breeding Plantation Tree Crops (Jain, S M and Priyadarshan, P M eds.). Springer, New York. p. 377-422.

SATTAR, M N; IQBAL, Z; TAHIR, M N; SHAHID, M S; KHURSID, M; AL-KHATEEB, A A and ALKHATEEB, S A (2017). CRISPR/Cas 9: A practical approach in date palm genome editing. Front. Plant Sci., DOI:10.3389/fpls.2017.01469.

SINGH, R; MEILINA, O A; LOW, E T L; MOHAMAD ARIF, A M; ROZANA, R; NOOKIAH, R; OOI, C L L; OOI, S E; CHAN, K L; MOHD AMIN, H; NORAZAH, A; JAYANTHI, N; BACHER, B; LAKEY, N; SMITH, S W; HE, D; HOGAN, M; BUDIMAN, M A; LEE, E K; DESALLE, R; KUDRNA, D; GOICOECHEA, J L; WING, R A; WILSON, R K; FULTON, R S; ORDWAY, J M; MARTIENSSEN, R A and SAMBANTHAMURTHI, R (2013). Oil palm genome sequence reveals divergence of interfertile species in old and new worlds. Nature, 500(7462): 335-339.

SITI NOR AKMAR, A; CHEAH, C S; AMINAH, S; LESLIE, C L O; SAMBANTHAMURTHI, R and MURPHY, D J (1999). Characterization and regulation of the oil palm stearoyl-ACP desaturase gene. J. Oil Palm Res Special Issue on Malaysia-MIT 
Biotechnology Partnership Programme: Vol. 2 - Oil Palm Metabolic Engineering: 1-17.

SITI NOR AKMAR, A; CHEAH, S C and NURNIWALIS, A W (2014). Expression regulatory elements. United States patent No. US 8,791,330 B2.

SITI NOR AKMAR, A and ZUBAIDAH, R (2008). Mesocarp-specific metallothionein-like gene promoter for genetic engineering of oil palm. J. Oil Palm Res. Special Issue on Malaysia - MIT Biotechnology Partnership Programme: Vol. 2 - Oil Palm Metobolic Engineering: 1-8.

SITI SURIAWATI, B; CHAN, P L; CHAN, K L; PARVEEZ, G K A and RASID, O A (2016). Meta analysis of multiple transcriptome data sets reveals mesocarp-specific genes in oil palm. $3^{\text {rd }}$ International Plant Breeding Conference. p. 79.

SONG, G; JIA, M; CHEN, K; KONG, X; KHATTAK, B; CHUANXIAO XIE, C; LI, A and MAO, L (2016). CRISPR/Cas9: a powerful tool for crop genome editing. The Crop J., 4: 75-82.

SUBRAMANYAM, K; SAILAJA, KV; SRINIVASULU, $\mathrm{M}$ and LAKSHMIDEVI, K (2011). Highly efficient Agrobacterium-mediated transformation of banana cv. Rashtali (AAB) via sonication and vacuum infiltration. Plant Cell Rep., 30: 425-436.

SVITASHEV, S; YOUNG, J K; SCHWARTZ, C; GAO, H R, FALCO, S C and CIGAN, A M (2015). Targeted mutagenesis, precise gene editing, and site-specific gene insertion in maize using Cas9 and guide RNA. Plant Physiol., 169: 931-945.

SYAHANIM, S; ABRIZAH, O; MOHAMAD ARIF, A M; IDRIS, A S and AMIRUDDIN, M D (2013). Identification of differentially expressed proteins in oil palm seedlings artificially infected with Ganoderma: A proteomics approach. J. Oil Palm Res. Vol. 25 (3): 298-305.

SYAHANIM, S; ABRIZAH, O; SITI NOR AKMAR, A; MOHAMAD ARIF, A M and H O, C L (2007). Cloning of an oleoyl-Coa desaturase from oil palm. Proc. of the PIPOC 2007 International Palm Oil Congress. MPOB, Bangi. p. 1001-1009.

SYUHADA, W N S; RASID, O A and PARVEEZ, G K A (2016). Evaluation on the effect of culture medium regeneration of oil palm plantlet from immature embryo. J. Oil Palm Res. Vol. 28 (2): 234-239.

TAHIR, N I; SHAARI, K; ABAS, F; ZAMZURI, I; TARMIZI, A H; AMIRUDDIN, M D; PARVEEZ, G K A and RAMLI, U S (2016). Metabolome analysis of oil palm clone P325 of different planting trials. J. Oil Palm Res. Vol. 28 (4): 431-441.
TEE, S S; TAN, Y C; ABDULLAH, F; ONG ABDULLAH, M and HO, C L (2013). Transcriptome of oil palm (Elaeis guineensis Jacq.) roots treated with Ganoderma boninense. Tree Genet. Genomes, 9: 377-386.

TEH, H F; NEOH, B K; WONG, Y C; KWONG, Q B; OOI, T E K; NG, T L M; TIONG, S H; LOW, J Y S; DANIAL,AD;ERSAD,MA;KULAVEERASINGAM $\mathrm{H}$ and APPLETON, D R (2014). Hormones, polyamines, and cell wall metabolism during oil palm fruit mesocarp development and ripening. J. Agric. Food Chem., 62 (32): 8143-8152.

TEH, HF; NEOH, B K; HONG, MPL; LOW, JYS; NG, T L M; ITHNIN, N; THANG, Y M; MOHAMED, M; CHEW, F T; YUSOF, H M; KULAVEERASINGAM, H and APPLETON, D R (2013). Differential metabolite profiles during fruit development in high-yielding oil palm mesocarp. PLoS One, 8(4): 1-10.

TRICK, H N and FINER, J J (1998). SAAT: sonicationassociated Agrobacterium-mediated transformation of soybean [glycine max (L.) Merrill] embryogenic suspension culture tissue. Plant Cell Rep., 17: 482488.

VAN AGGELEN, G; ANKLEY, G T; BALDWIN, W S; BEARDEN, D W; BENSON, W H; CHIPMAN, J K; COLLETTE, T W; CRAFT, J A; DENSLOW, N D; EMBRY, M R; FALCIANI, F; GEORGE, S G; HELBING, C C; HOEKSTRA, P F; IGUCHI, T; KAGAMI, Y; KATSIADAKI, I; KILLE, P; LIU, L; LORD, PG; MCINTYRE, T; O'NEILL, A; OSACHOFF, $\mathrm{H}$; PERKINS, E J; SANTOS, E M; SKIRROW, R C; SNAPE, J R; TYLER, C R; VERSTEEG, D; VIANT, M R; VOLZ, D C; WILLIAMS, T D and YU, L (2010). Integrating omic technologies into aquatic ecological risk assessment and environmental monitoring: hurdles, achievements and future outlook. Environ. Health Perspect., 118(1): 1-5.

WAN SARIDAH, W A; LAURA, B W; RHA, C K; ANTHONY, J S; RAMLI, U S; ABDUL MASANI, A M Y; PARVEEZ, G K A and SAMBANTHAMURTHI, $R$ (2008). Acetyl-CoA carboxylase from oil palm (Elaies guineensis) mesocarp. J. Oil Palm Res. Vol. 2: 97-107.

WIENKOOP, S; MORGENTHAL, K; WOLSCHIN, F; SCHOLZ, M; SELBIG, J and WECKWERTH, W (2008). Integration of metabolomic and proteomic phenotypes. Molecular \& Cellular Proteomics, 7(9): 1725-1736.

WOLT, J D; WANG, K and YANG, B (2016). The regulatory status of genome-edited crops. Plant Biotechnol. J., 14: 510-518.

WONG, Y C; TEH, H F; MEBUS, K; OOI, T E K; KWONG, Q B; KOO, K L; ONG, C K; 
MAYES, S; CHEW, F T; APPLETON, D R and KULAVEERASINGAM, H (2017). Differential gene expression at different stages of mesocarp development in high- and low-yielding oil palm. BMC Genomics, 18: 1-13.

YOUNG, M; COGBILL, S; JONES, G; FAULCON, T; GREEN, K; MCDANIEL, M; HARMON, G and BLACKMON, R (2008). Optimization of biolistics parameters in explants of rapid-cycling fast plants (Brassica rapa L.). J. North Carolina Academy Sci., 124 (2): 58-60.

YOUNIS, A; SIDDIQUE, M I; KIM, C K and LIM, K B (2014). RNA interference (RNAi) induced gene silencing: a promising approach of Hi-Tech plant breeding. Int. J. Biol. Sci., 10(10): 1150-1158.

YTTERBERG, A J; PELTIER, J B and VAN WIJK, K J (2006). Protein profiling of plastoglobules in chloroplasts and chromoplasts. A surprising site for differential accumulation of metabolic enzymes. Plant Physiol., 140: 984-997.

YUNUS, A M M; HO, C L and PARVEEZ, G $\mathrm{K}$ A (2008). Construction of $\mathrm{PHB}$ and PHBV transformation vectors for bioplastics production in oil palm. J. Oil Palm Res. Special Issue on MalaysiaMIT Biotechnology Partnership Programme: Vol. 2 - Oil Palm Metabolic Engineering: 37-55.

YUNUS, A M M and KADIR, A P G (2008). Development of transformation vectors for the production of potentially high oleate transgenic oil palm. Electronic J. Biotechnol. Vol. 11: 3.

ZUBAIDAH, R and SITI NOR AKMAR, A (2005). The effects of metal ions on root-specific expression of the oil palm MT3-B gene promoter. Proc. of the PIPOC 2005 International Palm Oil Congress. MPOB, Bangi. p. 1104-1110.

ZUBAIDAH, R; NURNIWALIS A W; SITI NOR AKMAR, A and PARVEEZ, G K A (2017). The use of Arabidopsis thaliana model system for testing oil palm promoter: case study on oil palm MT3-A promoter. J. Oil Palm Res. Vol. 29(2): 189-196.

ZUKER, A; AHRONI, A; TZIFIRA, T; BEN-MEIR, $\mathrm{H}$ and VAINSTEIN, A (1999). Wounding by bombardments yield highly efficient Agrobacteriummediated transformation of carnation (Dianthus carophyllus). Mol. Breed., 5: 367-375. 